\title{
Science teacher education in Thailand: a challenging journey
}

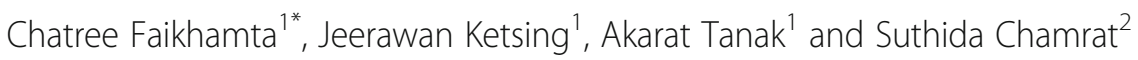

\author{
* Correspondence: \\ chatreechem@yahoo.com \\ ${ }^{1}$ Faculty of Education, Kasetsart \\ University, 50 Ngamwongwan Rd., \\ Chatuchak, Bangkok 10900, Thailand \\ Full list of author information is \\ available at the end of the article
}

\begin{abstract}
This article provides a description of science teacher education in Thailand, which is a key driver of the country's science education reform. We describe the history of science teacher education and consider its future by focusing on teacher qualifications, recruitment of teacher candidates, types of science teacher education programmes and teaching internships. This history indicates that the educational reform in 1999 had a big impact on science teacher preparation. Science teacher education programmes have been developed in order to produce constructivist science teachers. Recently, two types of science teacher education programmes have emerged: a five-year bachelor programme and a two-year master's programme. These programmes have been centrally framed by the Teacher Qualification Standards of the Teacher Council of Thailand (TCT). Even though each university has the authority to design its own courses and activities, the licensing, requirements and structure of the teacher education programme must follow the framework of TCT and the Higher Education Commission. The challenges that these programmes face are providing sufficient teacher preparation in respect to pedagogical content knowledge and reflective and research-based activities. Considering the future trends, this article provides recommendations for policymakers, curriculum developers, teacher educators and researchers.
\end{abstract}

Keywords: Science teacher education, Science education, Policy, Thailand

\section{Introduction}

Science teacher education in Thailand has been undergoing educational reform since 1999. The National Education Act and the 2001 Basic Education Core Curriculum addressed goals of science education in which skills in science and technology were recognized as a key catalyst in the development of a country's human resources (Institutes for the Promotion of Teaching Science and Technology (IPST) 2002). The basic education curriculum in Thailand is a 12-year core curriculum including a 9-year compulsory curriculum. The Thai science curriculum was initially developed as a standard-based curriculum. Core content and indicators for each grade level were provided to help teachers convey information through their teaching practices. These standards were developed by the Institute of the Promotion of Teaching Science and Technology (IPST) in 1999 to meet the national needs and help Thailand cope with modern advancements and globalization. These standards provided very brief objectives, curricular strands, indicators for curricular contents and learning outcomes, and assessment and evaluation methods for teaching and learning science subjects.

(c) The Author(s). 2018 Open Access This article is distributed under the terms of the Creative Commons Attribution 4.0 International License (http://creativecommons.org/licenses/by/4.0/), which permits unrestricted use, distribution, and reproduction in any medium, provided you give appropriate credit to the original author(s) and the source, provide a link to the Creative Commons license, and indicate if changes were made. 
Scientific literacy is regarded as the ultimate goal of science learning (Bybee 1997; Institutes for the Promotion of Teaching Science and Technology (IPST) 2002). Thus, all learners are expected to be scientifically literate. Their learning is aimed at enabling them to acquire scientific knowledge by using essential inquiry skills for investigations, identifying patterns from data and solving scientific and technological problems. The science curriculum, which is part of the aforementioned core curriculum, comprises eight strands: living things and processes of life; life and the environment; substances and properties of substances; forces and motion; energy; change process of the earth; astronomy and space; and nature of science and technology (Bureau of Academic Affairs and Educational Standards 2008). Furthermore, students at all grade levels are required to learn the content in all eight strands.

Accordingly, science teachers are introduced to teaching science under the constructivist view of learning and, accordingly, the main teaching approaches are inquiry-based learning, project-based learning and problem-based learning. Recent studies have shown that qualified teachers produce quality students and, ultimately, qualified citizens (Ingersoll 2007; Institutes for the Promotion of Teaching Science and Technology (IPST) and OECD 2017; Siribanpitak 2003). However, many studies have indicated that Thai science teachers place too much emphasis on memorization and assessmentdriven learning with a focus on fragmented knowledge, rather than scientific inquiry and core concepts (Atagi, 2002; Ketsing and Roadrangka 2010). There are some difficulties in implementing these teaching approaches. Ketsing and Roadrangka (2010) indicated that the major difficulty is teachers' misconception of inquiry. Science teachers hold a partial understanding of the inquiry concept and do not realize that inquiry is a method for investigating natural phenomena and that scientists use it to gain knowledge based on evidence. Most of the activities that teachers promote rely on a teacher-directed approach. Further, while some teachers are aware of the value and importance of inquiry, in practice, they reject it for a variety of reasons, such as time constraints, the current evaluation policies and values, and cultural and political influences (Faikhamta and Ladachart 2016). Another difficulty is the integration of the nature of science (NOS) in learning activities. This is a new strand in which teachers are required to help students understand NOS by integrating NOS aspects in science learning. Many studies have found that Thai science teachers hold naive views about the aspects of NOS (Buaraphan 2010). Some of them view science as a product of knowledge for the purpose of explaining natural phenomena. In their view, science is a search for reality in the external world through the use of rigorous scientific methods. NOS is taught in an implicit fashion, where teachers focus on skills associated with the scientific process, scientific thinking and scientific methods for carrying out experiments, rather than having explicit discussions about NOS aspects (Faikhamta 2013).

For these reasons, the Thai government and society have expressed serious concern about the quality of science education (OECD, 2016). Accordingly, the quality of science teachers is scrutinized and the government focuses on science teacher preparation as a promising means of improving science education. This article provides a brief overview of science teacher education in Thailand, based on empirical research and our perspectives and experiences as Thai science educators. In the body of the article, we describe the science education system, then we discuss science teacher education in terms of teacher qualification and licensing, recruitment of teacher candidates, types of 
science teacher education programmes and student teaching internships. All of these issues are presented in terms of both their past and present status. The last section of the paper provides recommendations for future science teacher education. It discusses the challenges, complexities and opportunities of science teacher education in the future using a sociocultural lens.

\section{Historical pathways of science teacher education}

From past to present, types of science teacher education programmes have been influenced by educational policy. The policy is a key tool for enhancing the number and quality of teachers. The purposeful policies that shape the quality of education in highperforming countries involve encouraging highly capable individuals to consider teaching and screening the applicants carefully to ensure that the most committed and capable pursue a teaching career, preparing prospective teachers well so that they are ready to teach on their first day, and supporting the development of their teaching practice early in their career (Darling-Hammond et al. 2017). Across Thailand, several policies have been implemented to improve the quality of initial teacher education since 1967. According to an Office of the National Education Comission (ONEC, 2015) report, science teacher education has a long history, and it divides this history into four main eras. The first era (1967-1986) was the period when the Thai government initiated a policy for increasing the population. The teacher shortage during this period was one of the challenges in science teacher education. Therefore, many teaching institutions were founded. While this increased the number of teachers, the quality of their teaching presented another challenge, and the government could not control this quality. In the second era (1987-1991), the demand for teachers decreased and the teacher quality problem persisted. Values to teacher professional was decreased and teaching profession became under average comparing to other professions. In the third period (1992-1996), the crisis of teacher education was solved by the initiation of many projects for recruiting talented students to pursue teacher education. As an incentive, these students received full scholarships to undertake their studies. However, the projects failed because the numbers of students enrolled in the teaching programmes remained lower than expected. The talented students did not want to be teachers because of the low salaries they received. Finally, in the recent era (1997-present), there has been educational reform. Policy makers more emphasized on quality of teachers who were able to teach student-centred approach. Smart students with good beliefs and attitude in teacher profession were recruited to become a teacher. These students got full scholarships throughout their study.

Historically, the significant changes in Thai science teachers' preparation process were the result of the establishment of the Institute for the Promotion of Teaching Science and Technology in 1972 to promote the teaching and learning of science in accordance with the policies laid out in the third National Economic and Social Development Plan (1972-1976). The policy was aimed at promoting scientific research and accelerating the production of teachers whose teaching and learning would change from a lecture-based to an inquiry-based approach. This change improved the teacher preparation programme, enabling it to produce science teachers who can teach in accordance with the published curriculum throughout the country in 1976. However, the policy did not especially emphasize effective recruitment strategies and strong teacher 
preparation. Therefore, there was an over-supply of teachers who did not meet the education system's quality needs. Since 1997, the educational policies have emphasized quality instead of quantity. The focus has been on improving the quality of university supervisors and the teacher preparation programme, the production process and upgrading the teaching profession (Office of the National Education Commission [ONEC] 1994). The policy requires science teachers to have teaching competencies, an understanding of the philosophy of science, process skills and a scientific attitude. However, the decrease in the number of teacher graduates progressively created a shortage of up to 1265 high school science teachers. Moreover, there was less faith in the teaching profession; fewer high school graduates chose to study to become teachers or it became a backup profession. Conversely, teaching is highly ranked in Singapore, and there is a very low attrition rate - less than 3\% annually (Darling-Hammond et al. 2017). Consequently, the sixth to eighth National Education Development Plans (1987-2001) had a policy to accelerate the production of teachers by recruiting smart students with positive beliefs about, and attitudes towards, the teaching profession.

There were two special projects launched for attracting those with high learning achievement to become science teachers. One was Khuruthayat, a project for producing teachers for local development, and the other one was Promotion of Science and Mathematics Talented Teachers (PSMT), for producing talented science teachers for talented students. The first project was part of a four-year science teacher education programme, while the second project was a one-year graduate diploma programme in education. Teacher candidates in both projects were awarded scholarships covering most or all costs, such as tuition fees and living expenses. The financial support had the potential to attract many students with knowledge, pedagogy and a positive attitude towards the teaching profession (Srisukvatananan et al. 2001). However, the number of teachers produced failed to meet the target (Office of the National Education Commission 1999). The quality of graduates under the eighth National Education Development Plan dropped dramatically in terms of content and pedagogy (Office of the National Education Commission 1999). Moreover, there was a shortage of teachers with specialized knowledge of science. Therefore, there was a decrease in science teachers with scientific qualifications. A study on science teaching in Thailand, before the educational reform implemented in the 2001 academic year, found that high school science teachers with a science degree constituted only $25 \%$ of the total number of science teachers (Sydhurum 2001). At the elementary level, all teachers had to teach science, but only $5 \%$ of them had a degree in teaching science (Institutes for the Promotion of Teaching Science and Technology (IPST) 2000).

Students who choose to study in the education field are a factor of change. The statistics relating to university and college admissions show that bright and intelligent students are increasingly getting into teacher programmes (Wattananarong 2011). This situation is similar to that 30 years ago, when teacher recruitment was successfully attracting the best students to the teaching profession pipeline. Two important lawsuits - Teachers and Educational Personnel Council Act B.E. 2546 (Government of Thailand 2003) and Teacher Civil Service and Educational Personnel Act, B.E. 2547 (Government of Thailand 2003) - resulted in teaching professionals becoming certified, receiving higher salaries and being incentivized. 
Despite Thailand's continuous policy of teacher production, the production of science teachers over the past 30 years has been insufficient. Most policies are set up to solve problems, as opposed to detailing a plan to put in place. The lack of coordination between policymakers, production and use units resulted in a production failure. The policy of the first era led to the production of some teachers in excess of the demand; however, there was still an insufficient production of science teachers. Neither were they sufficient in quantity nor did they meet the needs of the schools. The greatest shortage of science teachers was in schools under the Office of the Primary Education Commission, Bangkok Education Office and the Department of Education (ONEC 1997). The shortage indicated the popularity of teacher education, and the students who chose to study to be science teachers made only moderate achievements in their studies (Office of the National Education Commission 1986). During 1997-2002, teacher training schools could not produce enough teachers to meet the needs of schools (National Education Development Center of Thailand 1986. In addition, teachers were of low quality in terms of science content and teaching methods. In particular, science teachers were not qualified. Only $25 \%$ of science teachers graduated in science. This might be a result of the production process, which failed to select students with high achievement, faith, ideology and a positive attitude towards teachers (National Education Development Center of Thailand 1986). Based on an analysis of the curriculum of science teachers from 12 universities in the 2001 academic year, $37 \%-51 \%$ of their total credits represented content knowledge (Silpabanlaeng 2005). Pedagogical knowledge (PK) and content knowledge (CK) were taught separately. Subject matter or content knowledge were taught in the faculty of science, but the teaching profession was taught in the faculty of education and through teaching experience. Hence, there was no integration of theory and practice (Faikhamta and Roadrangka 2005).

By contrast, the preparation of students in Finland focused on the teaching of subject matter, rather than pure content courses. Students would simultaneously undertake coursework in the teaching of all subjects that they would eventually teach (60 credits). Moreover, it was found that Thai preservice science teachers were not adopting a student-centred approach, and they lacked innovation in their teaching, such as using media and technology (Silpabanlaeng 2005). Further, they had not learnt to teach in diverse contexts and had not conducted research on how to develop teaching and learning (Chulwatana 2000). Teachers not being recognized as equal to other professionals and the lack of promotion of teaching and motivation to become a teacher meant an inability to recruit smart, talented students to study to enter the teaching profession. In addition, the teacher preparation curriculum was inconsistent with the primary and secondary curricula and the teaching process focused on theory rather than practice.

\section{Present science teacher education Programmes}

During the educational reform movements, a science teacher preparation programme was developed. Recently, two important science teacher preparation programmes have been introduced: a five-year B.Ed. programme and a two-year M.Ed. programme. These two programmes have different goals and course structures, and they have some differences with respect to obtaining a teaching license. Details of the two programmes are described below. 


\section{Five-year Bachelor's degree Programme}

The first system, derived from a four-year teacher education programme, requires preservice teachers to study in a faculty of education. The pre-service teachers do coursework for 4 years and spend 1 year in a school to gain field experience. University faculties of education and a network of Rajabhat institutes conduct this programme for preparing science teachers. The bachelor programmes for science teacher preparation focus both on science content and pedagogy, and some programmes focus more on PCK.

Typically, the objective of these programmes is to prepare primary and secondary science teachers. In Thailand, science is a compulsory subject for students from Grades 1-12. Furthermore, it must be taught by a science subject teacher, not a class teacher. Primary pre-service teachers should be majoring in general science, while secondary pre-service teachers should be majoring in chemistry, biology or physics.

All pre-service teachers must adhere to a clear code of ethics to evince good manners as professional teachers. Additionally, institutions offering a B.Ed. degree must provide a minimum of 50 credits for teacher professional courses, 30 credits for general education courses and a minimum of 80 units of specialized courses (Teachers' Council of Thailand 2013). The teacher preparation curriculum needs to be approved and certified by the steering committee of the council. It is compulsory to follow every step of TCT course structure to meet the criteria for licensing graduates.

In addition to TCT, in 2009, OHEC established a framework for science teacher education programmes. Any teacher education programme would have to include six expected learning outcomes: code of ethics; knowledge; intellectual skills; interpersonal relationship skills; numerical, communication and technological skills; and teaching skills. OHEC also defined the structure of teacher education coursework, including four main areas: general education, teacher professional courses, science and elective courses.

Pre-service teachers are required to take at least 160 credits in three types of courses, including general education courses, teaching profession courses and elective courses as shown below.

\begin{tabular}{lll}
\hline 1. General education courses & 30 & Credits \\
1.1 Science and mathematics & 9 & Credits \\
1.2 Social sciences & 4 & Credits \\
1.3 Humanities & 3 & Credits \\
1.4 Languages & 12 & Credits \\
1.5 Physical education & 2 & Credits \\
2. Teaching profession courses & 133 & Credits \\
2.1 General pedagogy & 47 & Credits \\
2.2. Science content & 70 & Credits \\
2.3 Subject-specific pedagogy & 16 & Credits \\
3. Elective courses & 6 & Credits \\
\hline
\end{tabular}

Note: One credit means an hour per week for one semester.

General Education Courses are compulsory liberal arts courses for not only pre-service teachers but all undergraduate students. Teaching Profession Courses cover both science content and pedagogy courses. Elective Courses are generally any courses in other faculties which pre-service teachers can freely select depending on their own interests. 
The structure of science teacher education programmes in different institutions appears quite similar in terms of teaching professional courses. According to the regulations of the TCT, the typical teaching professional courses are Foundations of Education, Curriculum, Educational Psychology, Measurement and Education, Education System and Assurance, Classroom Management, Educational Research, ICT in Education and Student Teaching Internship. However, their characteristics differ from those of content-specific pedagogy courses. Most programmes include a scientific methods course, but only some have PCK-based courses, such as Science Process Skills, Science Projects, The Nature of Science, Science Curriculum Development and Assessment in Science Education. Rather than offering general pedagogy in teaching profession courses, some institutions focus on PCK. There is criticism of science CK in five-year science pre-service teacher education. Considerable research has revealed that pre-service teachers have insufficient science CK (e.g., Buaraphan et al. 2005). In order to cope with this problem, there has been an effort in recent science teacher education programmes to balance the credits between science content and pedagogy courses. Consequently, there is almost a 50:50 ratio today. The emphasis on $\mathrm{CK}$ is intended for students to have a stronger content background than in the past. Similar to almost all undergraduate science students, pre-service science teachers are required to take all science courses taught by scientists and typically in the faculty of science. For example, pre-service chemistry teachers must take courses covering all areas of chemistry, such as organic chemistry, inorganic chemistry, analytical chemistry, physical chemistry, and biochemistry.

Unfortunately, very few science education programmes provide pre-service teachers with both theoretical and practical experience. Even though science courses consist of theory and laboratory work, pre-service teachers have few opportunities to do scientific research with scientists in real situations.

Currently, admissions to pre-service teacher education programmes vary depending on the type of programme. For a five-year bachelor programme, institutions admit candidates both on the basis of their grade point average (GPA) in high school and their entrance examination score. After graduating from Grade 12, students can apply for further education in science education programmes. Typically, admission to the programme is determined by the student's score on their entrance examination. This paper and pencil-based test is the first tool for selecting student candidates.

After receiving the results of their entrance examination, candidates can choose any programme including science teacher education at any institution. Their admission will depend on their score ranking and the maximum number of students being admitted. Each institution has a different standard score which must be met for admission. Upon achieving an acceptable score, they will be interviewed by the committee for science teacher education at the institution. Historically, students who pass the entrance exam and are recruited into the science teacher education programme have shown a rather low performance compared to other programmes, such as science, engineering and medicine. As stated, the teaching profession is not an attractive career for high-performing students due to the low salary compared to that of a medical doctor or engineer (Ingersoll 2007; Siribanpitak and Boonyananta 2007). As shown in the university admission scores in 2016, the majority of pre-service science teachers admitted to well-known public universities had lower scores than those studying engineering or medical sciences (Association of the Council of University Presidents of Thailand 2016). Recently, however, their 
performance has improved, and sometimes their scores are higher than those of students admitted to science programmes.

\section{Two-year Master's degree Programme}

The second teacher preparation system is under the management of the project for the PSMT, supported by IPST. The Ministry of Education, Ministry of University Affairs and IPST collaboratively have undertaken the PSMT project since 2012. This project is seen as a key component of science teacher preparation for solving the problems of the quality and quantity of Thai science teachers. The objectives of the project are to produce high-ability science teachers and improve the teaching and learning of science in Thailand (Institutes for the Promotion of Teaching Science and Technology (IPST) 2014). For this reason, each student participating in this project receives a full scholarship covering tuition, living expenses, textbooks, research grants, etc. He or she will automatically become science teachers after graduation.

Unlike the five-year bachelor programme, the objective of the two-year master's programme is to prepare secondary science teachers majoring in chemistry, physics or biology. Students with outstanding academic performance in chemistry, physics or biology in a faculty of science are recruited to pursue a master's degree in science education in the faculty of education for 2 years. Students with outstanding academic performance in chemistry, physics or biology in a faculty of science are recruited to pursue a master's degree in science education in the faculty of education for 2 years. Recently, nine institutions were selected and approved by IPST to offer this programme. The structure of the programme may differ from one institution to the next, but it generally consists of at least 36 credits as shown below.

\begin{tabular}{lll}
\hline 1. Seminar in science education & 2 & Credits \\
2. Teaching profession courses & 31 & Credits \\
2.1 General pedagogy & 25 & Credits \\
2.2 Science content & 6 & Credits \\
2.3 Subject-specific pedagogy & 3 & Credits \\
3. Thesis & 12 & Credits \\
\hline
\end{tabular}

Like the five-year bachelor degree programme, teaching professional courses in the two-year master's degree programme are designed on the basis of the regulations of TCT. Pre-service teachers must do a student teaching internship for 1 year; thus, they must complete all the coursework in 1 year. These courses are generally Foundations of Education, Curriculum, Educational Psychology, Measurement and Evaluation, Education System and Assurance, Classroom Management, Educational Research, ICT in Education and Student Teaching Internship. Accordingly, there is criticism directed at the two-year science teacher education programme for including too many courses. According to TCT, each institution has to design the programme to cover the teaching standards, which results in a heavy course load (Pongsophon et al., 2016). However, because of the shorter period of time, some courses in some institutions may offer fewer credits and more integrated course contents. For example, instead of having a general Curriculum course, the course may be designed as Science Curriculum Development. Examples of courses in the two-year master's degree programme are as follows: 
- Foundations of Education for Science Teachers

- Language and Culture for Science Teacher

- Science Curriculum Development

- Construction and Utilization of Science Instructional Media and Innovation

- Assessment in Science Education

- Research in Science Education

- Teaching and Learning Chemistry (or Biology or Physics)

Since Pre-service teachers have particular subject specializations, such as chemistry, physics and biology, a methods course is designed to fit their major. Hence, instead of a Scientific Methods course, there is a Chemistry Methods course.

As part of the PSMT project, all pre-service teachers are required to do classroom action research for their master's thesis. Typically, they conduct their classroom action research when they are participating in the student teaching internship. In the first semester of their student teaching, pre-service teachers may identify problems with their teaching and then develop their research questions. They may subsequently develop their research proposal and collect and analyse data in the first or second semester.

Gaining admission to the two-year master's degree programme is quite a rigorous process, which is conducted according to the regulations of PSMT. About 580 students each year are prepared to be PSMT science teachers. These teachers are expected to be leaders in science and mathematics teaching and learning in high schools. Teacher candidates must hold a Bachelor of Science degree in chemistry, biology or physics with a GPA of at least 2.75 (out of 4.00) and have obtained an English proficiency score of at least 500 on the TOEFL exam and 5.0 on the IELT exam (Institutes for the Promotion of Teaching Science and Technology (IPST) 2014). A teacher candidate can choose to apply to any three out of 11 universities, and each university determines the number of students to admit. After submitting their applications, teacher candidates will take an examination to assess their science CK and their attitude towards the teaching profession. PSMT committees are in charge of developing tests and evaluating the test scores. If the candidates pass the exam, they will be interviewed by a group of PSMT committee and faculty members at the host university. The final decision regarding admission will be in the hands of these committee members.

\section{Student teaching internship}

The internship is a key component of science teacher education that is intended to bridge the gap between the academic coursework and the realities of classroom teaching. It is a period during which pre-service teachers learn how to teach a particular content topic to specific students and develop their teaching ability in a real classroom setting. The internship can help pre-service teachers integrate their CK with their PK to generate PCK (Faikhamta 2011).

Recently, the content and implementation of the internship course have relied on TCT teacher standards. During the final year of their B.Ed. or M.Ed. programme, preservice teachers devote two 18-week-long semesters at a local primary or secondary school. This one-year long internship was initiated under assumption that one semester of student teaching may not be enough to prepare the new teacher for a lasting career in the field of education. A year-long model may more adequately prepare the new 
teacher in terms of their self-esteem and experience at tackling the everyday tasks. Even though it seems too long for pre-service teachers working at schools for a yearlong, most of them feel satisfied with this condition. If a teacher graduate from a 5-year B.Ed. or 2-year M.Ed. programs with a yearlong internship, he or she will earn higher salary than from other 4-year bachelor programs.

In the first semester of the internship, the pre-service teachers teach science for 8 to $12 \mathrm{~h}$ per week. Then, in the second semester, which is the focus of this study, they are required to teach science for six to eight hours per week and conduct a classroom action research project, in which university supervisors and cooperating teachers assess both of the pre-service teachers' action research projects.

Similar to other countries such as Finland (Evagorou et al. 2015) and Singapore (Tan et al. 2012), student teaching internships in Thailand are research-oriented. It is believed that the opportunity to conduct action research helps pre-service teachers develop their contentspecific pedagogy. Through action research, pre-service teachers systematically examine the way in which they plan lessons, teach and reflect on their science teaching. In order to enhance their PCK and change their understanding of science learning and teaching, preservice teachers are expected to recognize their own experiences of learning, question their beliefs and contemplate their teaching of specific content and in specific contexts. For example, they may investigate how to teach Grade 6 students the force and motion concept using an inquiry-based approach. However, Faikhamta and Clarke (2015) found that most pre-service science teachers held very limited views of action research and lacked confidence when carrying out action research, especially at the beginning of their student teaching. They viewed action research methods in terms of almost purely experimental approaches to research.

The pre-service teachers are required to attend seminars at the university throughout their internship. The purpose of these seminars is to track the pre-service teachers' progress by discussing their problems, successes and challenges in teaching. During the internship, cooperating teachers and supervisors are expected to provide front-line advice, support and critical feedback to the pre-service teachers. As such, they are critical collaborators in the action research undertaken by the pre-service teachers.

Even though the internship has been promoted as a method for professional development in teacher education, Thai pre-service science teachers' PCK during their internship is limited. Faikhamta (2011) noted that several pre-service science teachers in B.Ed. programmes had difficulties in implementing student-centred approach. They were also concerned with designing and organizing activities when planning their lessons. It was quite difficult for them to decide how to write the expected learning outcomes and how to begin and sequence learning activities. Some pre-service teachers reflected that the learning outcomes they intended to reach were too general and did not show what science concepts or skills the students were expected to acquire. Another concern was limited conceptual understanding of science. Some pre-service science teachers discussed the fact that science concepts were too complex and difficult for them. They felt that they held misconceptions about many concepts. This concern inhibited them from choosing key concepts and designing learning activities.

In addition, supervision by cooperating teachers and university supervisors has an important role in providing pre-service teachers with opportunities to develop their PCK for teaching science. Based on the findings of Faikhamta and Clarke (2015) and Jantarakantee 
and Roadrangka (2010), pre-service science teachers rarely receive productive suggestions and feedback from cooperating teachers about their teaching. They noted that some cooperating teachers did not have any experience or understanding of student-centred approach or constructivist-based teaching and suggested that the pre-service teachers consult with their supervisors. However, it was apparent that the cooperating teachers need university supervisors to clarify the role of these cooperating teachers when they supervise pre-service science teachers in their teaching. Cooperating teachers also often feel that teacher education programmes are disconnected from their work. While university supervisors and pre-service teachers work collaboratively, they and cooperating teachers have limited opportunities to directly communicate with one another. This problem may be because of traditional models of supervision that are based on a 'theory into practice' model. In this model, pre-service teachers learn theories in their university courses and then apply their knowledge in a teaching setting.

\section{Teacher qualification and licensing}

As with teachers of other subjects, teacher certification and licensing in Thailand for science teachers is centralized and organized by two organizations: TCT and OHEC. Pre-service teachers can automatically receive their certification and teaching licence after completing the science teacher education programme, without having to take any further examinations, provided their programme is approved by these two organizations. According to TCT and OHEC, the development and implementation of national professional standards enhance the professionalism, quality and status of teachers.

TCT issues teaching licences and sets out standards for the profession. The standards make explicit a set of minimum and essential desired attributes of teachers, which serve as the benchmark for all teacher education programmes at all institutions. The current standards cover three main dimensions - namely, professional knowledge and experience, practice and ethics (Teachers' Council of Thailand 2013). Professional knowledge and experience comprise nine strands: teacherhood; educational philosophy; languages and culture; psychology for teachers; curriculum, teaching and classroom management; research for developing students' learning; ICT for education; measurement and evaluation for learning; and educational assurance. In practice, pre-service teachers are required to complete two strands - observation and participation in school - and a oneyear student teaching internship. To help pre-service teachers with their practice, the teacher education programme must include activities with the following objectives:

1. Regularly engage in academic activities related to professional development

2. Undertake various activities while taking into account the outcomes for students

3. Commit to developing students such that they reach their full potential

4. Develop teaching plans for practical implementation

5. Regularly develop effective instructional media and materials

6. Organize instructional activities that focus on generating positive and long-lasting outcomes for students

7. Systematically report the results of students' quality development

8. Act as a good role model for students

9. Constructively cooperate with others in the school community

10. Creatively cooperate with others in other communities 
11. Seek out and use information for one's own development

12. Create opportunities for students to learn from all kinds of situations

Interestingly, all teacher education programmes must include a one-year internship for pre-service teachers to complete the licensure requirements. This is very restrictive. A prospective teacher who desires to obtain a teaching licence must gain at least 1 year (360 h) of experience in a school, including at least $210 \mathrm{~h}$ of classroom teaching. To meet the school experience requirement, science teacher preparation programmes extend student teaching from one semester to two semesters.

Certification mainly limits science teachers to the subjects and grade levels for which they have received teacher education. A certified science teacher may be able to teach science subjects from $\mathrm{K}-12$ according to the particular programme that they completed. For example, if the science teacher majored in chemistry, this certified teacher may teach chemistry rather than general science. However, a certified teacher who majored in general science teaching may teach science at the elementary and middle school levels, rather than chemistry, biology or physics at the high school level.

Unlike other teacher education programmes, science teacher education is guided by Science Teacher Standards developed by IPST. These standards describe the teacher's integration of knowledge, skills and ability, comprising 10 strands: the nature of science; ethical use of science and technology; leaner learning and individual differences; curriculum and instruction; science communication; scientific inquiry; assessment and evaluation; and school-community development (Institutes for the Promotion of Teaching Science and Technology (IPST) 2002). However, IPST's standards are not official regulations for earning a certification. They only provide guidance on pre-service and in-service teacher education.

Not surprisingly, this situation creates difficulties for institutions to develop unique science teacher education. Many institutions have been confronted with applying too many standards and framework in their science education programme. Most of the standards focus on pedagogy or content, rather than on the integrated PCK. Based on the research of Rakpolamaung et al. (2016), TCT's standards are overwhelming and inflexible. The standards should be more flexible and allow institutions to define their own standards and framework. Recently, all teacher education programmes have adopted a rather similar structure, as they must meet the same requirements. According to the recommendations from a panel of experts, teacher certification should be specific to each grade level. For example, separate certifications exist for elementary and secondary teachers, and these experts believe that elementary teachers should be able to teach all subjects, not only science.

\section{Recommendations for future science teacher preparation}

In the future, TCT will need a reinvention, for example, of the teacher standard that shapes and directs the curriculum of the teaching degree programmes. It is obvious that the perspective of the present teacher education courses still reflects the Silo model of the teaching profession which is focused on specialized content. The compulsory teacher standards continue to reflect only general education, while for the contents of specific subjects, students must learn from a specialized faculty or college. Pre-service teachers in science need to enroll in a faculty of science to take science 
courses. The concept behind this structure of TCT standards is that teacher education and subject matter education are separate. The concept of PCK was introduced in the new model of teacher education, which has resulted in the Thai qualifications framework for higher education in the education field. The document 'Thailand Qualification Framework of Education (5-year program)', published in 2011, clearly states that the courses for pre-service teachers must reflect the concepts of PCK (Ministry of Education 2011). This phenomenon indicates that Thailand was trying to shift from separate notions of pedagogy and specific content to (at least) the integration of PK and CK. Ironically, the same document clearly states that 'students must learn their major subject from the faculty that provides course in that subject' and the 'faculty of education must not build a laboratory or recruit specialized teachers in that specific subject, to prevent an overlap with those faculties providing major subject courses' (Ministry of Education 2011, p. 5). This document also provides conflicting conceptual frameworks of PCK. Indeed, a faculty of education with science education courses must have a science laboratory, for either primary or secondary school student teachers, if they are to learn in a context that reflects PCK. The faculty members must also have PCK to exhibit authentic scientific inquiry in courses provided by the faculty of education.

In addition to the conception of course structure, TCT can determine the characteristics of future teachers. Those characteristics are as important as teacher knowledge, because this will influence their future students. Indeed, teacher attributes are considered to be the most important elements that affect students (Guerriero 2017). Unlike Singapore's framework for teacher education, TCT teacher standards more focus on teacher knowledge and also unclearly guide the design, delivery, and enhancement of teacher programs to develop constructivist teachers with positive values. National Institute of Education (NIE) in Singapore developed a model of V3SK which represents the underpinning philosophy of teacher education. This model focuses on a three-dimensional paradigm including values, skills and knowledge that permeate teacher education program and curricula (Tan et al. 2012).

The faculty of education or teacher's college should not only emphasize general pedagogy but also more focus on content-specific pedagogy. The way to recruit science teacher educators might also have to change. Science teacher educators need to be strong in a specific content background and also specialize in general pedagogy. This follows the model of medical education, where the instructor of medical students is also a doctor with a clinical or research background. In contrast, most science teacher educators in faculties of education or teacher's colleges in Thailand lack practical teaching experience, and a large portion of them have never taught in a school. Research has shown that the experiences of teacher educators are crucial for effective teacher education (John 2002). Teacher educators are not the only factor in successful teacher preparation. Teacher mentors are also important for student teachers. During their teaching practicum in a school, pre-service teachers develop characteristics, attitudes and practice under the supervision of their mentor. Even after graduating to become in-service teachers, novice teachers need a teacher induction to help them maintain their early career while they develop professional skills. For teacher education to be successful in Thailand, teacher educators, mentors in the school and teacher induction need to be emphasized to achieve quality, meet the standards and make contributions as well as to recruit and develop more teachers in the future. 
Furthermore, the idea of school-university partnerships (Breault 2013) or a professional learning community (PLC) for preparing future science teachers is something new to Thai culture. Generally speaking, cooperating teachers and university mentors have not routinely participated in collaborative coaching and mentoring of their trainees. It is rare to see open communication between the three stakeholders - pre-service teachers, cooperating teachers and university mentors (Faikhamta 2011; Jantarakantee and Roadrangka 2010). Consequently, researchers have often found that one of the major stumbling blocks for pre-service teachers' professional growth is the mismatch of advice from cooperating teachers and university mentors (Faikhamta 2011; Ketsing 2017).

In the internship component of teacher education programmes, with the collaborative atmosphere created by cooperating teachers and university supervisors, pre-service teachers should have opportunities to develop their science PCK, (content knowledge and the nature of science, knowledge of science curriculum; knowledge of student conceptions and learning; knowledge of instructional strategies; and knowledge of assessment). Bradbury et al. (2017) and Chan and Yung (2015) stated that PCK is considered subject-specific teaching, and the teaching is therefore unique and specific to particular contexts. Therefore, opportunities are provided for teaching in real situations with students and fostering reflection on one's own prior knowledge and beliefs. The results of Kosnik and Beck (2000) found strong support for university supervisors and elements of the seminar sessions, such as presenting research proposals and discussing with peers and university supervisors.

Finally, science teacher education programmes in Thailand should offer more reflective experience. The key features of this kind of programme are that the pre-service science teacher is seen as a learner, a teacher of science, a critical inquirer, a reflective practitioner and a critical friend (Bell and Gilbert 1994; Sperandeo-Mineo et al. 2005). Metacognition should be embedded in various contexts (Abell and Bryan 1997; Gunstone et al. 1993) as a series of activities including university-based seminars, lessons and classroom action research. Metacognition should be continually encouraged in all activities, including planning, teaching, reflection on teaching, giving feedback, constructive discussions with students on learning in a particular context, and collaboratively working with others. In this idea, reflection on one's own teaching and other people's teaching, such as peers and classroom teachers, is the key to helping pre-service teachers become aware of the strengths and weaknesses of their own and others' teaching, and improve their teaching. It gives pre-service teachers opportunities to critique and discuss student conceptions, learning outcomes in the science curriculum, specific teaching strategies, instructional media, assessment methods and lesson planning. The development of pre-service teachers in this context is consistent with the suggestions in the literature supporting teachers' PCK (Bertram and Loughran 2011; Zembal-Saul et al. 2000).

\section{Conclusions}

Thailand is currently in the middle of a transition, and many challenges are affecting the success of science teacher education in the country. The first challenge involves national policies and regulators. During this era of transition, the key game changer for Thai teacher education is TCT (Mattavarat et al. 2017). Science teacher preparation programmes must be approved and certified by the steering committee of the council. Moreover, to meet the criteria for graduating licensed teachers, it is compulsory for institutions to follow every step of the TCT course structure. 
The second challenge relates to the fact that most science teacher preparation programmes are aimed at specific disciplines, such as teaching science at the elementary level and chemistry, biology or physics at the secondary level. Pre-service teachers have few opportunities for interdisciplinary or transdisciplinary learning or for learning how to teach an integration of the aforementioned disciplines. This may create difficulties in teaching science in the future, which is more focused on interdisciplinary learning, such as in STEM education.

The third challenge involves the proportions of CK, PK and PCK courses. As mentioned above, in most of the courses in science teacher education programmes, the focus is on CK and PK, and less so on PCK. Pre-service teachers are expected to integrate $\mathrm{CK}$ and $\mathrm{PK}$ automatically in their student teaching. Therefore, it seems important to ask when and how many PCK courses should be provided for pre-service science teachers during their teacher education programme.

The fourth challenge concerns the inadequate quality of training programmes. Some programmes focus on rote learning and lecture-based teaching, with outdated knowledge of progressive approaches to teaching and teacher education. There are many issues in science education on which both teacher educators and pre-service teachers must update their knowledge. New approaches to teaching science in the twenty-first century, such as argument-based inquiry, STEM education, context-based learning and the model-based approach, should be addressed in science teacher education programmes.

The last challenge regards the quality of research-based student teaching internships. Recently, pre-service teachers have been undertaking their action research simply as a compulsory task required for their teacher education programme. Few pre-service teachers, university supervisors and school teachers view action research as an inquiry process enabling pre-service teachers to better understand their own beliefs and enhance their constructivist-based teaching practice. It should be a tool for enhancing pre-service teachers' learning of how to teach particular science content.

To prepare qualified science teachers in Thailand by equipping them with highquality teaching skills, we have suggested that authority figures and stakeholders who deal with science teacher preparation should consider at least the following issues: recruitment of high-performing candidates, appropriate course structure (e.g. CK, PK and PCK), updated issues and content in science education and high-quality researchbased student teaching internships.

Acknowledgements

Not applicable.

Funding

No funding.

Availability of data and materials

Not applicable.

Authors' contributions

All authors contributed equally to this work. All authors commented on the manuscript at all stages. All authors read and approved the final manuscript.

Authors' information

Chatree Faikhamta is an Associate Professor at Faculty of Education, Kasetsart University, Thailand. He has taught a full range of undergraduate and graduate courses in science education such as chemistry methods course, research design in science education, science teacher professional development, etc. His research areas focus on pedagogical content knowledge (PCK), self-study research and action research. He directed the nationally funded Developing 
PCK-based professional development program for prospective science teachers and their school supervisors. Chatree is involved in collaborative research in many countries such as Canada, Japan, Korea, Spain, and Taiwan. Jeerawan Ketsing is an Assistant Professor of Science Education at Faculty of Education, Kasetsart University, in Bangkok. She teaches STS, research design in science education, action research, and environmental education. In addition to teaching, Jeerawan Ketsing has been conducting research with cooperating teachers for nurturing preservice science teacher professional growth for 10 years. Her primary research activities focus on inquiry-based learning, reflective practice, and environmental education. In her spare time, Jeerawan loves to practice mediation, run, and travel. Akarat Tanak is an Assistant Professor at Faculty of Education, Kasetsart University, Thailand. She has taught science education for both undergraduate and graduate courses such as science learning management at the elementary level, scientific thinking, science instructional media and innovation for nine years. Her research areas focus on using context-based learning approach and inquiry based learning to develop science teaching and learning. Currently, the research on the development of pre-service science teachers' technological pedagogical content knowledge (TPACK) is her interest.

Suthida Chamrat is a lecturer at Faculty of Education, Chiang Mai University, Thailand. She had been a chemistry teacher at a secondary school and a science educator at Bureau of Academic Affairs and Education Standards, Ministry of Education for 13 years. Currently, she has taught science education for both undergraduate and graduate levels. Her expertise lies in instructional design that reflects both Nature of Science and Technology (NOST). Her research focuses on the transformative learning by innovative pedagogy related science teacher professional development such as STEM Education, ICT integrated learning, etc.

\section{Competing interests}

The authors declare that they have no competing interests.

\section{Publisher's Note}

Springer Nature remains neutral with regard to jurisdictional claims in published maps and institutional affiliations.

\section{Author details}

${ }^{1}$ Faculty of Education, Kasetsart University, 50 Ngamwongwan Rd., Chatuchak, Bangkok 10900, Thailand. ${ }^{2}$ Faculty of Education, Chiang Mai University, Su Thep, Mueang Chiang Mai District, Chiang Mai 50200, Thailand.

Received: 22 October 2017 Accepted: 31 January 2018

Published online: 20 February 2018

\section{References}

Abell, S. K., \& Bryan, L. S. (1997). Reconceptualizing the elementary science methods course using a reflection orientation. Journal of Science Teacher Education, 8(3), 153-166.

Association of the council of university presidents of Thailand. (2016). Addition scores in academic year 2016. Retrieved from http://admission.cuas.or.th/adm60maxmn/.

Atagi, R. (2002). The Thailand educational reform project: School reform policy. Report to the office of the national education commission (ONEC). Bangkok: ONEC.

Bell, B., \& Gilbert, J. (1994). Teacher development as professional, personal, and social development. Teaching and Teacher Education, 10(5), 483-497.

Bertram, A., \& Loughran, J. (2012). Science teachers' views on CoRes and PaP-eRs as a framework for articulating and developing pedagogical content knowledge. Research in Science Education, 42(6), 1027-1047.

Bradbury, L. U., Wilson, R. E., \& Brookshire, L. E. (2017). Developing elementary science PCK for teacher education: Lesson learned from a secondary grade partnership. Research in Science Education. https://doi.org/10.1007/s11165016-9607-X.

Breault, D. A. (2013). The challenges of scaling-up and sustaining professional development school partnerships. Teaching and Teacher Education, 36, 92-100.

Buaraphan, K. (2010). Pre-service and in-service science teachers' conceptions of the nature of science. Science Educator, 19(2), 35-47.

Buaraphan, K., Singh, P., \& Roadrangka, V. (2005). Exploring third-year pre-service physics teachers' concepts of force and motion. Songklanakarin Journal of Social Sciences and Humanities (supp.), 11, 45-69.

Bureau of Academic Affairs and Educational Standards. (2008). Indicators and science core concepts in accordance with the national science standards B.E. 2551. Bangkok: The Agricultural Cooperative Service of Thailand Limited.

Bybee, R. (1997). Achieving scientific literacy. Portsmouth: Heineman.

Chan, K. K., \& Yung, B. H. (2015). On-site pedagogical content knowledge development. International Journal of Science Education, 37(8), 1246-1278

Chulwatana, M. (2000). Report on policy of the National Education Act B.E. 2542. Government agreement with Asian Development Bank, system reform policy, government changes the demographic structure of the country to education on education and role of the Faculty of Education in reform of learning and reform of teacher profession. Bangkok: Funny Publishing.

Darling-Hammond, L., Burns, D., Cambell, C., Goodwin, L., Hammerness, K., Low, E., McIntyre, A., Sato, M., \& Zeichner, K. (2017). Empowered educators: How high-performing systems shape teaching quality around the world. California: Jossey-Bass.

Evagorou, M., Dillon, J., Viiri, J., \& Albe, V. (2015). Pre-service science teacher preparation in Europe: Comparing preservice teacher preparation programs in England, France, Finland and Cyprus. Journal of Science Teacher Education, 26(1), 99-115.

Faikhamta, C. (2011). Fifth year pre-service science teachers' struggles with and learning about teaching science through a-year-long field experience. Kasetsart Journal (Social Science), 32(1), 140-147. 
Faikhamta, C. (2013). The development of in-service science teachers' understandings of and orientations to teaching the nature of science within a PCK-based NOS course. Research in Science Education, 43(3), 847-869.

Faikhamta, C., \& Clarke, A. (2015). Science student teachers' struggles with and learning about classroom action research during their field experiences. Asia-Pacific Journal of Education, 35(2), 259-273.

Faikhamta, C., \& Ladachart, L. (2016). Science education in Thailand: Moving through crisis to opportunity. In C. Mei-Hung (Ed.), Science education research and practice in Asia. The Netherlands: Springer.

Faikhamta, C., \& Roadrangka, V. (2005). Problems in professional experience training of student teachers in the project for the promotion of science and mathematics talented teachers (PSMT). Songklanakarin Journal of Social Sciences and Humanities, 11(2), 151-1624.

Government of Thailand. (2003). Teachers and educational personnel council act B.E.2546 (2003). Bangkok: The Government Gazette.

Guerriero, S. (2017). Teachers' pedagogical knowledge and the changing of nature of teaching profession. Paris: OECD Publishing.

Gunstone, R. F., Stattery, M., Baird, J. R., \& Northfield, J. R. (1993). A case study exploration of development in preservice science teacher. Science Education, 77, 47-73.

Ingersoll, R. M. (2007). A comparative study of teacher preparation and qualifications in six nations. Consortium for Policy Research in Education, RB-47, 1-15.

Institutes for the Promotion of Teaching Science and Technology (IPST). (2014). Project for the promotion of science and mathematics talented teachers (PSMT) phase 3 (2012-2018). Bangkok: IPST.

Institutes for the Promotion of Teaching Science and Technology (IPST) \& OECD. (2017). PISA 2015 results in focus: Executive summary. Bangkok: IPST.

Institutes for the Promotion of Teaching Science and Technology (IPST). (2000). Report of the results of the data collection to design long-term master plan and master plan 2002-2006. Bangkok: Karusapa Press.

Institutes for the Promotion of Teaching Science and Technology (IPST). (2002). Science and technology teacher standards. Bangkok: Karusapa Press.

Jantarakantee, E., \& Roadrangka, V. (2010). The cooperating teachers' and the university supervisors' understanding of classroom research, principles and the supervision of classroom research for pre-service science teachers. Kasetsart Journal (Social Science), 31(3), 319-332.

John, P. D. (2002). The teacher educator's experience: Case studies of practical professional knowledge. Teaching and Teacher Education, 18(3), 323-341.

Ketsing, J. (2017). Preservice science teachers' challenges in doing classroom action research and learning activities to cope with the challenges. Kasetsart Journal of Social Sciences, 38(1), 457-469.

Ketsing, J., \& Roadrangka, V. (2010). A case study of science teachers' understanding and practice of inquiry-based instruction. Kasetsart Journal of Social Sciences, 31, 1-16.

Kosnik, C., \& Beck, C. (2000). The action research process as a means of helping student teachers understand and fulfil the complex role of the teacher. Educational Action Research, 8(1), 115-135.

Mattavarat, S., Viseshsiri, P., \& Siribanpitak, P. (2017). Proposed policy for preparation of high-quality primary school teachers in Thailand. Kasetsart Journal of Social Sciences, 38(2), 105-110.

Ministry of Education. (2011). Notification of the Ministry of Education: Qualifications framework for higher education in education. Retrieved http://www.mua.go.th/users/tgf-hed/news/FilesNews/FilesNews6/education5year_m1.pdf.

National Education Development Center of Thailand. (1986). Summary of research and seminar of the teacher training reform project. Nonthaburi: Sukhothai Thammathirat University Press.

OECD. (2016). PISA 2015 results in focus. Paris: OECD Publishing.

Office of the National Education Commission. (1986). The sixth National Education Development Plan (1987-1991). Bangkok: Rungruengsarn Publishing.

Office of the National Education Commission. (1997). Evaluation Report of the seventh National Education Development Plan (1992-1996) teachers and educational personnel. Bangkok: ONEC.

Office of the National Education Commission. (1999). Report on the evaluation of the National Plan for the development of the 8th National Education in the first two years (1997-1998). Bangkok: ONEC.

Office of the National Education Commission [ONEC]. (1994). Evaluation report of the eight National Education Development Plan (1987-1991) teacher training. Bangkok: ONEC.

Office of the National Education Commission. (2015). State of teacher education and professional development in Thailand. Bangkok: ONEC.

Pongsophon, P., Suksawang, J., Pitipontapin, S., Pimtong, P., Tanak, A., Ketsing, J., Jatarakantee, A., Faikhamta, C. (2016). Evaluation of Kasetsart PSMT project. Bangkok: Kasetsart University.

Rakpolamaung, C., Pitiyanuvath, S., Preededilok, F., Charungkaittikul, S., Maneelek, S., \& Bangchaod, D. (2016). State and problems of teacher production, utilization and development of basic education teachers. Bangkok: Chulalongkorn University.

Silpabanlaeng, R. (2005). The trend of pre-service science teacher education in the period of fifteen years (2002-2016). Doctor of philosophy thesis in science education. Bangkok: Kasetsart University.

Siribanpitak, P. (2003). Research report on policy development and education plan for reforming teachers, university professors, and education personnel. Bangkok: Pimdee Co., Ltd.

Siribanpitak, P., \& Boonyananta, S. (2007). Chapter 7 the qualifications of the teaching force in Thailand. In R. M. Ingersoll (Ed.), A comparative study of teacher preparation and qualifications in six nations Retrieved from http://files. eric.ed.gov/fulltext/ED498318.pdf.

Sperandeo-Mineo, R. M., Fazio, C., \& Tarantino, G. (2005). Pedagogical content knowledge development and pre-service physics teacher education: A case study. Research in Science Education, 36(3), 235-268.

Srisukvatananan, P., Chaiso, P., Roadrangka, V., \& Yutakom, N. (2001). Evaluation report of the promotion of science and mathematics talented teacher project (PSMT) first four years (1996-1999). Bangkok: Kasestart University.

Sydhurum, P. (2001). Science education in Thailand: Documentation for the round table meeting between Thai - United States January 2001. Bangkok: Institutes for the Promotion of Teaching Science and Technology (IPST). 
Tan, O. S., Liu, W. C., \& Low, E. L. (2012). Educational reforms and teacher education innovations in Singapore. In O. S. Tan (Ed.), Teacher education frontiers: International perspectives on policy and practice for building new teacher competencies (pp. 71-91). Singapore: Cengage Learning Asia.

Teachers' Council of Thailand. (2013). Teaching profession standards. Retrieved from http://www.ksp.or.th/ksp2013/ content/view.php?mid=136\&did=254.

Wattananarong, K. (2011). When teacher profession is first choice. Retrieved from https://www.thairath.co.th/content/162903.

Zembal-Saul, C., Blumenfeld, P., \& Krajcik, J. (2000). Influence of guided cycles of planning, teaching, and reflection on prospective elementary teachers' science content representations. Journal of Research in Science Teaching, 37(4), 318-339.

Submit your manuscript to a SpringerOpen ${ }^{\odot}$ journal and benefit from:

- Convenient online submission

- Rigorous peer review

- Open access: articles freely available online

- High visibility within the field

- Retaining the copyright to your article

Submit your next manuscript at $>$ springeropen.com 